\title{
Economic efficiency of the nuclear power industry and social aspects of its development
}

\author{
Artem S. Lukyanets ${ }^{1,2}$, Toan Nguyen Canh $^{3}$, Evgeniya M. Moiseeva ${ }^{1}$ \\ ${ }^{1}$ Institute of Socio-Political Research under the Russian Academy of Sciences \\ 6 Fotievoy St., bldg. 1, Moscow, 119333, Russian Federation \\ 2 Peoples' Friendship University of Russia (RUDN University) \\ 6 Miklukho-Maklaya St., Moscow, 117198, Russian Federation \\ ${ }^{3}$ Institute of European Studies under the Vietnamese Academy of Social Sciences \\ 176 Thai Ha St, Dong Da Dist, Hanoi, Vietnam
}

\begin{abstract}
The article attempts to develop a system of parameters for an objective and comprehensive assessment of the efficiency of the nuclear power industry in terms of its contribution to the country's economic and social development, as well as its environmental well-being and its geopolitical position. Currently, nuclear power industry makes up a significant part of the energy supplies in the developed countries throughout the world. However, in the developing economies, including those of East and Southeast Asia, it plays a less prominent role. Nevertheless, in recent years, China has been the leader in commissioning new atomic facilities, thanks to the consistent implementation of its state program for the development of the nuclear power industry. Forecasts indicate that in the near future, the share of atomic energy will remain stable and account for about $10 \%$ of all global energy capacity, which is confirmed by the estimates made during the study. However, in the long term nuclear energy cannot be ignored as an economically efficient and environmentally friendly source of energy, as well as a factor in improving the quality of life of the population when developing a strategy for the sustainable development of a country. The article examines the already existing assessment criteria for the economic efficiency of nuclear power plants (NPPs), and proposes new standards for the assessment of its contribution to the development of the community and a country's stance on the global political stage. The article also identifies the main obstacles to the further development of the industry in the modern world. The research showed that the main specific feature of an NPP operation from the economic point of view is extremely high initial construction and commissioning costs, with relatively low further operation costs, which determines long payback lines and liquidity shortages reducing the attractiveness of such projects for potential investors. These peculiarities determine the leading role of state authorities in the launch, operation and modernization of nuclear power facilities.
\end{abstract}

Keywords: nuclear power, development, environment, economic efficiency, life standards, geopolitical position

\section{Introduction}

In the XX century, the nuclear power industry became one of the most technologically equipped and knowledge-intensive industries. Today nuclear power is a "mature" technology that provides a significant contribution to the production of electricity throughout the world. Nevertheless, its development was erratic and difficult, and in some countries it stopped at the stage of public debate. The greatest success in mastering 
atomic power generation technologies was achieved by the OECD countries, which now account for nearly $90 \%$ of the total output. The leaders in the nuclear power production are the United States, France, South Korea, Russia, and Japan (where most of the reactors are currently stopped). In the 1990s, several countries that previously did not develop the atomic energy industry decided to launch it. Among them were Iran, Turkey, Belarus, Egypt, India, Bangladesh and others.

The history of the nuclear power engineering can be divided into two periods, which are opposed to each other to some extent. The first period, from the 1960s to the early 1990s, was characterized by its rapid growth and capacity building in the leading countries of the world. In the face of a sharp rise in the cost of oil and gas, atomic energy was the best solution to meet the growing electricity needs. The second period, throughout the 1990s to the present days, is characterized by a sharp decline in the number of newly introduced nuclear facilities, and in some countries a reduction up to the complete closure of nuclear power plants. The pretext for that was the accident at the US Three Mile Island NPP in 1979, and even a more horrible accident at the USSR Chernobyl NPP which followed in 1986. These events exacerbated the already imminent crisis around the safety of nuclear power plants and its impact on human health and the environment. The fear engulfed all the leading countries of the world, which had a dramatic effect on the further development of nuclear power engineering. So the average annual growth in NPPs' capacity in the years following the accident was only $2.5 \mathrm{GW}$, or about three reactors, which is several times less than in the 1970-1980s ${ }^{1}$.

However, the nuclear power industry did not cease to exist due to its high adaptability and complexity of functioning. It is very difficult and capital-intensive to start a nuclear power plant, and it is even more difficult to decommission it in a short time, when its life-cycle has not come to an end. The life-cycle of an NPP is a highly specific feature of its operation, and as a rule is lasts for at least 40 years. Modern NPPs are designed with a view of an operating period of 60 years ${ }^{2}$.

While the excitement about nuclear power in the countries of the "old world" (primarily the EU countries) is fading away, the new industrial countries, primarily in the East and Southeast Asia, seem to be more and more enthusiastic about it. Currently, the leader in the commissioning of new capacities is China, which has set a goal of building 100 operating reactors by 2020 .

The global policy to reduce carbon dioxide emissions aimed at preventing and reducing the negative impact of human activity on the environment might open a new chapter in the development of nuclear energy in the medium term. In 2015, at the Climate Conference in Paris held under the UN Framework Convention on Climate Change, an increase in electrical generation at nuclear power plants was identified as one of the major ways to reduce greenhouse gas emissions into the atmosphere along with a gradual decrease in the share of thermal power plants which are the major producers of carbon dioxide. The same was proclaimed by the Director General of the International Atomic Energy Agency

1 The Economics of nuclear power. World Nuclear Association. URL: http://www.world-nuclear. org/uploadedfiles/org/info/pdf/economicsnp.pdf (accessed: 15.01.2018).

${ }^{2}$ Godovoy otchet AO Koncern Rosehnergoatom za 2016 god [Annual report of JSC Concern Rosenergoatom for 2016]. URL: http://www.rosenergoatom.ru/upload/iblock/673/6736f56972480f dbf340e e640b0882c4.pdf (accessed: 04.07.2018). 
(IAEA), Yukiya Amano at a meeting of the UN General Assembly in 2015. He stressed that nuclear energy plays a decisive role in reducing global temperature rise and its negative consequences (Lukyanets, Ryazantsev, 2016).

\section{Methodological aspects of nuclear power plants performance evaluation}

The potential risk of radioactive contamination of the environment and its negative impact on people and the society is not the only obstacle in the nuclear power industry's further development. The efficiency of nuclear power plants performance, the ratio of the funds invested and the returns obtained, as well as its impact on the economy and the society are far more important. Unfortunately, in the case of the nuclear power generation industry it is impossible to make all the necessary calculations using routine methods in order to answer decisively to the question whether nuclear power is actually a cheap source of electricity.

The issue still stirs up disagreements among leading economists. Each scientist or group of scientists provides convincing calculations based on empirical data; however, they produce completely different results derived from the same initial figures. The error lies not in the inaccuracy of calculations or the source data, but in the methodology of the research itself, its hypothesis and in the approach used. Our study revealed the practical impossibility of using direct methods for calculating performance indicators for NPPs and the entire nuclear industry. Technological complexity, high potential environmental risks, huge initial investments, alongside with geopolitical factors make nuclear power engineering a specific area of scientific and economic research. In this regard, the opponents of the nuclear power industry operate with the indicators (for example, the payback period of investments), which are not relevant in their essence. It is impossible to simply calculate the cost of one megawatt of nuclear energy in the first or second year of an NPP's operation and build any argument on such estimates.

Nuclear energy is one of the highest scientific achievements of the mankind, so for obvious reasons it cannot be fully implemented by a single company. Nuclear power production is inextricably intertwined in all major processes in the life of a country and the society. It is integrated into them, and the degree of this integration determines its security, the quality of life of the population, and in some countries (like Japan) the state of the entire economy.

Among the numerous works dedicated to assessing nuclear power plants performance we would like to highlight the paper of S. Hirschberg which proposes a methodology based on a set of major indicators, divided into groups by their application areas such as economy, environment or society. Each group includes a number of specific indicators, such as nuclear fuel price elasticity, fuel availability, employment, environmental impact, and others (Hirschberg et al., 2004). In our opinion, taking into account the international situation, it is necessary to enhance this scheme by such an indicator as geopolitical consequences for the country from launching nuclear power facilities. From our point of view, only the application of an integrated approach in assessing the economics of the nuclear power industry will allow to conduct a balanced evaluation and give an accurate answer to the initial research question. The minimum set of criteria and assessment indicators is presented in the table 1. 


\section{Criteria and indicators for the assessment of energy facilities}

\begin{tabular}{|c|c|}
\hline Application area & Indicator \\
\hline \multirow[t]{9}{*}{ Economy } & Sources of financing \\
\hline & Cost of financial resources \\
\hline & Initial financial investments \\
\hline & Operating (current) activity of the object \\
\hline & Cost and availability of raw materials (nuclear fuel, oil, coal gas) \\
\hline & Production costs in the calculation of the standard service life of the object \\
\hline & $\begin{array}{l}\text { The degree of dependence of production costs on changes in the price of raw } \\
\text { materials }\end{array}$ \\
\hline & Cost of waste disposal \\
\hline & Environmental protection costs \\
\hline \multirow[t]{6}{*}{ Social sphere } & Cumulative number of jobs created \\
\hline & $\begin{array}{l}\text { Remuneration in comparison with the average values for the industry and for } \\
\text { the country as a whole }\end{array}$ \\
\hline & The development of science and advanced technology \\
\hline & $\begin{array}{l}\text { Dynamics of the level of education of the population in the adjacent territories } \\
\text { (primarily satellite cities) }\end{array}$ \\
\hline & $\begin{array}{l}\text { Impact on public health (number of diseases, number of deaths) from the } \\
\text { functioning of industry objects }\end{array}$ \\
\hline & $\begin{array}{l}\text { Changes in the standard of living of the population in the adjacent territories } \\
\text { (primarily satellite towns) }\end{array}$ \\
\hline \multirow[t]{5}{*}{ Environment } & Greenhouse gas emissions \\
\hline & Environmental impact (radiation background, air, water and land pollution) \\
\hline & Land and water use \\
\hline & Recycling and disposal of industrial waste \\
\hline & Costs of environmental activities \\
\hline \multirow[t]{3}{*}{ Geopolitical factors } & The prestige of the country in the international arena \\
\hline & Energy security of the country \\
\hline & $\begin{array}{l}\text { The degree of independence from external factors, incl. due to changes in } \\
\text { macroeconomic conjuncture }\end{array}$ \\
\hline
\end{tabular}

Source: Compiled by the authors.

This set of criteria is not exhaustive and can be extended depending on the territory, time, as well as the economic and geopolitical position of the country.

\section{Economic aspects of the nuclear power industry}

Economic factors were one of the most important drivers of the growing popularity of nuclear energy in the second half of the XX century. The sharp rise in oil prices in 1973, followed by a rise in gas and coal prices, forced the governments of many developed countries to look for alternative energy sources that would be less susceptible to cyclical fluctuations inherent in traditional energy sources (Wald, 1980). Nuclear power became the tool that contributed to the subsequent stabilization of prices for traditional energy sources.

Atomic energy production technology is fundamentally different from the traditional energy production technologies. The main difference is high initial investment and 
relatively low current operating costs. In terms of initial investment, with account of current energy prices, the nuclear power falls in between traditional energy sources (oil, coal, gas) and alternative energy sources (wind, sun, tides) ${ }^{1}$. The indisputable advantage of atomic energy is low volatility in prices and almost complete independence on world prices on oil, gas, coal, as well as uranium. The technological process of NPP operation involves the reloading of fuel every year or 1.5 years, while the fuel assemblies themselves serve for 5-6 years, which is also a certain factor of stability and predictability of the final cost of electricity produced by an NPP (Lukyanets, Nguyen Canh Toan, 2016).

When studying the economic aspects of nuclear energy production, it is necessary to consider in detail every single component of its total costs.

1. Initial capital costs. As mentioned above, high initial investments are a specific feature of the nuclear power industry. They consist of the site preparation and construction and personnel training costs and generally account for $70 \%$ of the total costs. Often they include the costs of equipping the station's personnel (building a satellite city or an urbantype settlement), as well as the costs of financing itself, if a bank loan was involved. NPP accidents of past years impose exceptional safety requirements on modern plants, which also affect initial investments. However, the experience of South Korea and China clearly demonstrates that continuous programs for the development of atomic technologies and innovative technologies introduction help to reduce significantly the time needed to build and launch an NPP, as well as its initial investment costs. Over the past 15 years, the term of commissioning of new facilities in these countries has decreased and averaged from 48 to 58 months, with a worldwide average term of 74 months.

2. Operating costs. This type of costs is associated with the costs of maintaining the current activities of an NPP including the costs of fuel, personnel, routine maintenance of the equipment, as well as the costs of nuclear waste disposure. This category can be divided into two subcategories: fixed costs and variables. The former do not depend on the energy out-turn, i.e. they are constant. These include depreciation, maintenance, and salaries of operating personnel. The latter are variable and derive from of the amount of energy produced. High proportion of variable transaction costs associated primarily with the cost of fuel is a special feature of energy production from traditional sources. Nuclear power production is free from this disadvantage. The share nuclear fuel costs in the total cost of energy is relatively small. Even if the cost of fuel increases twice, the cost of energy produced from it increases only by $7 \%$.

3. External and indirect costs. These may take place in the event of unforeseen and emergency situations during the operation of nuclear power facilities. In such a case, their value might be huge. But while the operation is normal, these costs are 0 , and minor accidents' rectification costs are usually covered by insurance.

4. Other costs. Other costs include the possible environmental fees, and taxes of a particular country.

A comparative study by the Atomic Energy Agency shows that at the beginning of the XXI century, the competitiveness of nuclear energy has increased. That was promoted by both direct and indirect factors. Direct factors include an increase in the efficiency of

${ }^{1}$ Uranium Information Centre. The Economics of Nuclear Power. Briefing paper 8. 2004. URL: http://www.uic.com.au/nip08.htm (accessed: 04.09.2016). 
nuclear reactors, which reduced the cost of $1 \mathrm{kWh}$ of energy produced from nuclear fuel, as well as an increase in gas prices, which was observed until 2015. Indirect factors include legal requirements and restrictions on carbon dioxide emissions in a number of countries (first of all, in the EU) which gave additional competitive advantages to nuclear energy in the long term ${ }^{1}$.

\section{The quality of life of the population and nuclear energy}

Nuclear power as a high-tech sector of economy performs a number of major social functions, primarily related to increasing the level of employment, the emergence of new jobs, and improving the quality of life for workers in the industry. In the USA, every dollar invested in the nuclear power industry brings $\$ 1.04$ to the local budget, $\$ 1.18$ to the state budget, and $\$ 1.87$ to the federal budget. In 2010, $1 \mathrm{MW}$ of nuclear power brought an additional $\$ 470$ million to the US economy, of which $\$ 35$ million fall to the wage fund 2 .

Our study showed that the largest number of jobs is created in the nuclear power industry, and the wages of the employees is well above the national average. According to the US Bureau of Labor Statistics, in 2017 an average salary in the nuclear power industry was $\$ 91370$ per year, or $\$ 43.93$ per hour $^{3}$. At the same time, nationwide, average wage was only $\$ 30.533$ per year and $\$ 25.98$ per hour. In Russia as well, nuclear energy workers earn more than an average salary. According to the annual report of Rosenergoatom, the average monthly income of the company's employee in 2016 amounted to 80.567 rubles per month, with the national average wage of 36.709 rubles ${ }^{4}$.

An even bigger economic and social effect is achieved taking into account the multiplicative effect of the construction and subsequent operation of nuclear power facilities. An average cost of a modern nuclear power plant ranges from $\$ 6$ billion to $\$ 8$ billion. (Borzunova, Maksimova, Morozova, 2017). The minimum number of workers at the construction site in the active phase of the construction reaches 3.500 people. Construction of a nuclear power plant implies increased requirements for the qualifications of workers and their level of education, both during the construction and during its operation. According to approximate data, the construction of just one nuclear power unit requires more than 300 thousand cubic meters of concrete, 66 thousand tons of steel, $60 \mathrm{~km}$ of pipelines, and over $500 \mathrm{~km}$ of electrical wires ${ }^{5}$. All this creates an additional

1 Projected Costs of Generating Electricity. The OECD Nuclear Energy Agency (NEA), 2005. URL: https://www.oecd-nea.org/ndd/pubs/2005/5968-projected-costs.pdf (accessed: 24.05.2018).

2 Nuclear Energy's Economic Benefits - Current and Future. Nuclear Energy Institute. URL: https://www.nei.org/corporatesite/media/filefolder/policy/papers/jobs.pdf (accessed: 24.05.2018).

3 Occupational Employment and Wages, May 2016. Nuclear Power Reactor Operators. The Bureau of Labor Statistics of the U.S. URL: https://www.bls.gov/oes/current/oes518011.htm (accessed: 24.05.2018).

4 Srednemesyachnaya nominalnaya nachislennaya zarabotnaya plata rabotnikov po polnomu krugu organizacij v celom po ehkonomike Rossijskoj Federacii v 1991-2017gg. Rosstat, 2017 [The average monthly nominal accrued wages of employees for a full range of organizations in general for the economy of the Russian Federation in 1991-2017. Rosstat, 2017]. URL: www.gks.ru/free_doc/new_site/ population/trud/sr-zarplata/t1.docx (accessed: 24.05.2018).

5 Nuclear Energy's Economic Benefits - Current and Future. Nuclear Energy Institute. URL: https://www.nei.org/corporatesite/media/filefolder/policy/papers/jobs.pdf (accessed: 11.05.2018). 
positive economic and social effect in related sectors of the economy, thereby increasing the level of employment, and economic growth rates in the economy of a region or country, making a significant contribution to the country's GDP. The maintenance and operation of nuclear power plants, as well as other facilities related to it in the aggregate provides additional job places, thereby raising the standard of living of the population, and contributes to the demand for goods from the population, and thus increases the economic power of the country.

\section{Environment}

Paradoxically, with proper operation nuclear power is one of the most environmentally friendly and clean energy sources. In fact the side-product of an NPP is water vapor, which does not pose any threat to the environment. Modern technologies have made it possible to achieve such an absolutely safe mode of its operation. Table 2 presents the data on different sources of radioactive contamination of the territory in modern conditions.

Table 2

Sources of radiation to the environment and to humans

\begin{tabular}{|l|c|}
\hline \multicolumn{1}{|c|}{ Source } & Dose $(\mu \mathrm{R} / \mathrm{hr})$ \\
\hline Roentgen & 10 \\
\hline 5-hour flight by plane & 3 \\
\hline $75 \mathrm{~km}$ zone of a coal power station & 0.03 \\
\hline $75 \mathrm{~km}$ zone of a nuclear power plant & 0.009 \\
\hline The average annual dose of exposure & 360 \\
\hline
\end{tabular}

Source: World Health Organization. URL: http://www.who.int/ionizing_radiation/env/cosmic/en/index1 . html; World Nuclear Association. URL: http://www.world-nuclear.org/gallery.aspx (accessed: 04.01.2018).

It is clearly seen that the contribution of atomic energy to the radiation background is minimal compared to the other sources of radiation. Another advantage is the absence of greenhouse gas emissions into the atmosphere, which are typical of thermal power plants, especially coal-fired. The volumes of emissions and waste produced by nuclear power plants and fossil-fuel power plants are incomparable in size. The only kind of energy production that has a smaller impact on the environment is the solar and wind power generation, however they are characterized by comparatively high costs and a low level of efficiency, which depends on uncontrollable natural factors.

The main hazard of nuclear energy is spent fuel. Modern methods of its processing and conservation minimize the impact of its disposal on the environment. In any case, with the proper operation of a nuclear power plant, its impact on the environment will be noticeably lower than of a thermal power plant.

\section{Conclusion}

Nuclear energy is a modern, high-tech, time-tested source of alternative energy that if used properly, does not harm the environment and humans. In the XXI century, 
the nuclear power industry faced challenges that significantly slowed down its systematic and progressive development. One of them was the accident at the Japanese nuclear power plant Fukushima-1 in 2011, which forced the Japanese government to suspend the work of almost all nuclear power plants in the country under the influence of the massive protests as a new wave of fears of radiation contamination and the total destruction of mankind came. The economy of Japan suffers from energy problems today more than ever. The country's imports of reduced natural gas and oil sharply increased, as well as the prices for utilities for both businesses and the public. And despite the fact that it was the human factor which caused the accident, the event gave a new impetus to public discussions around the safety of nuclear power plants.

Another reason for the abandonment of nuclear power plants is their high costs. Opponents of nuclear energy talk about billions of dollars spent on NPPs' construction, but their view of the problem is one-sided and fails to embrace the whole picture, with regard to the multiplicative effect of the nuclear power industry on a national economy as a whole.

Having comprehensively examined the current global trends in energy markets, the geopolitical situation and the balance of power, we came to the conclusion that the real reasons behind putting the brakes on the development of nuclear energy in the world are the strong lobby of the largest oil, gas and coal companies, as well as geopolitical games and confrontation.

First, the active development of the nuclear power industry will lead to a big decline in the demand for traditional energy sources, which is extremely disadvantageous for the world's largest exporters.

Secondly, the development of its own nuclear power sector increases a country's energy security and makes it less dependent on external influences. In the context of geopolitical tensions, a number of leading economies, primarily the United States, are not interested in the increase in energy self-sufficiency of certain states, especially the new industrialized countries of Asia. The only exceptions are a few of such countries, among which we should name China of course. This country, which has already gained an outstanding economic power in previous years, wants to be completely independent from external energy suppliers to support its further economic growth.

A detailed analysis of the situation around the construction of nuclear power plants in Vietnam shows that it was rather influenced by geopolitical factors than by economic ones. The official pretext that the construction of nuclear power plants is unprofitable in the face of a downturn in prices for the traditional energy carriers seems extremely unwise and short-sighted.

Summarizing the economic aspects of nuclear energy, the following conclusions can be made:

- nuclear energy is a competitive technology for the production of electricity, along with both traditional and alternative sources;

- the cost of nuclear fuel is barely correlated with the prices for traditional energy sources, and therefore is not exposed to conjunctive fluctuations;

- the cost of nuclear fuel in the total cost of nuclear energy is negligible, which allows to build long-term pricing forecasts; 
- continuous development and investment in nuclear power is a factor in reducing the costs of initial investment;

- atomic energy is a factor in improving the quality of life of the population, its welfare and the level of education.

(C) Lukyanets A.S., Nguyen Canh Toan, Moiseeva E.M., 2018

This work is licensed under a Creative Commons Attribution 4.0 International License

\section{References}

Borzunova T.I., Maksimova A.S., Morozova G.F. (2017). The estimation of possible socio-economic consequences of nuclear power station building in Vietnam province Nin Thuan. RUDN Journal of Economics. Vol. 25 (3). Pp. 381-392. doi: 10.22363/2313-2329-2017-25-3-381-392 (In Russ.)

Hirschberg S., Dones R., Heck T., Burgherr P., Schenler W., Bauer C. (2004). Sustainability of Electricity Supply Technologies under German Conditions: A Comparative Evaluation. PSI report. No. 04-15.

Lukyanets A.S., Ryazantsev S.V. (2016). Economic and socio-demographic effects of global climate change. International Journal of Economics and Financial Issues. Vol. 6. No. S8. 269 p.

Wald M. (6 November, 1980). Cost of Nuclear Power. The New York Times. Late City Final ed. B3.

Lukyanets A.S., Nguyen Canh Toan. (2016). Atomnaya energetika kak faktor ekonomicheskogo razvitiya i ekologicheskoy stabil'nosti. Nauchnoe obozrenie. Seriya 1: Ekonomika i parvo. No. 6. Pp. 57-66. (In Russ.)

\section{Acknowledgements}

The article was prepared with the financial support of the Russian Foundation for Basic Research RFBR(OGON), project No. 16-22-09001.

\section{Article history:}

Received: 10 September 2018

Revised: 31 October 2018

Accepted: 26 November 2018

\section{For citation:}

Lukyanets A.S., Nguyen Canh Toan, Moiseeva E.M. (2018). Economic efficiency of the nuclear power industry and social aspects of its development. RUDN Journal of Economics, 26(4), 598-608. DOI: $10.22363 / 2313-2329-2018-26-4-598-608$

\section{Bio Note:}

Artem S. Lukyanets, Cand. Sci. (Econ.), Leading Researcher, the Institute of Socio-Political Research under the Russian Academy of Sciences (ISPR RAS); Associate Professor, the Department of International Economics, the Peoples' Friendship University of Russia (RUND University). Contact information: e-mail: artem_ispr@mail.ru

Toan Nguyen Canh, Dr. Sci (Econ), Professor, Researcher, the Institute of European Studies under the Vietnamese Academy of Social Sciences (VASS). Contact information: e-mail: okabc007@ yahoo.coml.ru

Evgeniya M. Moiseeva, Researcher, the Institute of Socio-Political Research under the Russian Academy of Sciences (ISPR RAS).Contact information: e-mail: evgeniyamoiseeva@mail.ru 


\title{
Экономическая эффективность атомной энергетики и социальные аспекты ее развития
}

\author{
А.С. Лукьянец ${ }^{1,2}$, Тоан Нгуен Кань ${ }^{3}$, Е.М. Моисеева ${ }^{2}$ \\ ${ }^{1}$ Институт социально-политических исследований Российской академии наук \\ Российская Федерация, 119333, Москва, ул. Фотиевой, д. 6, корп. 1 \\ 2 Российский университет дружбы народов \\ Российская Федерация, 117198, Москва, ул. Миклухо-Маклая, 6 \\ ${ }^{3}$ Институт европейских исследований Вьетнамской академии общественных наук \\ 176 Тай Ха, Донг Да, Ханой, Вьетнам
}

\begin{abstract}
В статье делается попытка выработать систему параметров объективной и всесторонней оценки эффективности функционирования атомноэнергетической отрасли с точки зрения ее вклада в экономическое и социальное развития страны, а также ее экологическое благополучие и положение на международной политической арене. В настоящий момент атомная энергетика вносит заметный вклад в энергетический баланс развитых стран мира. Менее заметную роль она играет в энергообеспечении развивающихся стран, в том числе Восточной и Юго-Восточной Азии. Однако в последние годы лидером по вводу в эксплуатацию новых атомных мощностей является Китай, где последовательно реализуется соответствующая программа развития энергетической отрасли. Средневзвешенные прогнозы говорят о том, что в ближайшей перспективе удельный вес атомной энергии останется стабильным и составит порядка $10 \%$ от всех вырабатываемых мощностей, что подтверждается оценками, сделанными в ходе исследования. Однако в долгосрочной перспективе при выработке стратегии устойчивого развития стран атомная энергетика не может быть оставлена без внимания как экономически эффективный и экологически безопасный источник энергии, а также фактор повышения качества жизни населения. В статье последовательно рассматриваются существующие критерии оценки экономической эффективности атомных электростанций (АЭС) и предлагаются новые параметры оценки, связанные с вкладом атомной энергетики в развитие социальной сферы жизни страны и повышение ее геополитической независимости, помимо того выявлены основные препятствия для дальнейшего развития данной отрасли в современном мире. Установлено, что главной особенностью функционирования АЭС с экономической точки зрения являются исключительно высокие первоначальные затраты на строительство и ввод в эксплуатацию при относительно низких издержках на дальнейшую эксплуатацию, что определяет длительные строки окупаемости и дефицит ликвидности, снижающие привлекательность подобных проектов для потенциальных инвесторов. Эти и другие особенности обуславливают ведущую роль органов государственной власти в запуске, эксплуатации и модернизации мощностей атомной энергетики.
\end{abstract}

Ключевые слова: атомная энергетика, развитие, экология, экономическая эффективность, уровень жизни, геополитическое положение

\section{История статьи:}

Дата поступления в редакцию: 10 сентября 2018

Дата проверки: 31 октября 2018

Дата принятия к печати: 26 ноября 2018

\section{Для цитирования:}

Лукьянеи А.С., Нгуен Кань Тоан, Моисеева Е.М. Economic efficiency of the nuclear power industry and social aspects of its development (Экономическая эффективность атомной энер- 
гетики и социальные аспекты ее развития) // Вестник Российского университета дружбы народов. Серия: Экономика. 2018. T. 26. № 4. C. 598-608. DOI: 10.22363/2313-2329-201826-4-598-608

\section{Сведения об авторах:}

Лукьянеи Артем Сергеевич, кандидат экономических наук, ведущий научный сотрудник Центра социальной демографии Института социально-политических исследований Российской академии наук; доцент кафедры международных экономических отношений Российского университета дружбы народов. Контактная информация: e-mail: artem_ispr@ mail.ru

Нгуен Кань Тоан, доктор экономических наук, профессор, научный сотрудник Института европейских исследований Вьетнамской академии общественных наук. Контактная информация: e-mail: okabc007@yahoo.com

Моисеева Евгения Михайловна, младший научный сотрудник Центра социальной демографии Института социально-политических исследований Российской академии наук. Контактная информация: e-mail: evgeniyamoiseeva@mail.ru 